\title{
Effects of Asian Dust (KOSA) Deposition Event on Bacterial and Microalgal Communities in the Pacific Ocean
}

\author{
Teruya Maki*, Akira Ishikawa ${ }^{1}$, Fumihisa Kobayashi, Makiko Kakikawa, Kazuma Aoki ${ }^{2}$, \\ Tomoki Mastunaga, Hiroshi Hasegawa and Yasunobu Iwasaka ${ }^{3)}$ \\ College of Science and Engineering, Kanazawa University, Kakuma, Kanazawa, Ishikawa 920-1192, Japan \\ ${ }^{1)}$ Graduate School of Bioresources, Mie University, 1577 Kurimamachiya, Tsu, Mie 514-8507, Japan \\ ${ }^{2)}$ Department of Earth Sciences, Faculty of Science, University of Toyama 3190 Gofuku, Toyama 930-8555, Japan \\ ${ }^{3)}$ Frontier Science Organization, Kanazawa University, Kakuma, Kanazawa, Ishikawa 920-1192, Japan
}

*Corresponding author. Tel: +81-76-234-4793, E-mail: makiteru@t.kanazawa-u.ac.jp

\begin{abstract}
Atmospheric aerosol deposition caused by Asian dust (KOSA) events provide nutrients, trace metals, and organic compounds over the Pacific Ocean that enhance ocean productivity and carbon sequestration and, thus, influence the atmospheric carbon dioxide concentrations and climate. Using dust particles obtained from the snow layers on Mt. Tateyama and the surface sand of Loess Plateau in incubation experiments with natural seawater samples on a shipboard, we demonstrate that dust-particle additions enhanced the bacterial growth on the first day of incubation. Gram-positive bacterial group and alpha-proteobacteria were specifically detected form seawater samples including the mineral particles. Although the remarkable dynamics of trace elements and nutrients depend on dust-particle additions, it is possible that organic compounds present in the mineral particles or transported microbial cells could also contribute to an increase in the quantities of bacteria. The chlorophyll concentrations at fractions of every size indicated a similar pattern of change between the seawater samples with and without the dust-particle additions. In contrast, the chlorophyll measurement using submersible fluorometer revealed that the dynamics of phytoplankton composition were influenced by the dust-particles treatments. We conclude that the phytoplankton that uses the bacterial products would increase their biomass. We show that KOSA deposition can potentially alter the structures of bacterial communities and indirectly influence the patterns of marine primary production in the Pacific Ocean.
\end{abstract}

Key words: KOSA, Bacteria, Ocean, Phytoplankton, Dust-particles, Nutrients

\section{INTRODUCTION}

The aerosol particles transported by KOSA events are a large source of nutrients, trace metals, and organic matter placed into the Pacific Ocean. The input increases ocean phytoplankton biomass and affects microbial diversity (Donaghay et al., 1991). In some areas of the Pacific Ocean, photosynthetic and heterotrophic microbial communities are known to be nutrient-limited, and dust deposition events containing bioavailable phosphorus can stimulate the activity and the production of nutrient-limited microorganisms (Spokes and Jickells, 1996; Prospero and Savoie, 1989). In ocean areas where iron, phosphorus and/or nitrogen are deficient, aerosol deposition can supply both iron and phosphate, nutrients that increase primary production, export production, and carbon sequestration (Erickson et al., 2003; Duce and Tindale, 1991; Blank et al., 1985). During glacial periods, increases of primary production by dust deposition will reduce atmospheric carbon dioxide concentrations and, thus, impact climate dynamics (Moore et al., 2006). The materials transported by dust can enhance ocean productivity and carbon sequestration and, thus, influence atmospheric carbon dioxide concentrations and climate.

Dust particles contain a source of organic carbon for aquatic ecosystems (Pulido-Villena et al., 2008) and cause the simultaneous addition of organic matter and phosphorus by dust events (Lekunberri et al., 2010). The input by dust is expected to induce the growth of heterotrophic bacteria more than that of autotrophic microorganisms (Pulido-Villena et al., 2008; Herut et $a l ., 2005)$. In addition to the inputs of nutrients associated with dust, viable bacteria can be transported for long distances (Iwasaka et al., 2009; Kellogg and Griffin, 2006). Aerosol particles can supply some microorganisms as well as inorganic and organic compounds to seawater (Hervàs et al., 2009). Our previous 
study demonstrated that the microorganisms were associated with dust particles recorded in the snow cover at Mt. Tateyama that could be transported from China (Maki et al., 2011). Some reports investigated the microbial dynamics in the seawater and lake water samples that were spiked with dust particles and incubated under laboratory controlled conditions (e.g., Lekunberri et al., 2010; Paytan et al., 2009). However, the artificial effects of laboratory-controlled incubation condition on the microbial structures could not be neglected. Furthermore, the detail species structures of phytoplankton and bacteria were not simultaneously analyzed in the same water samples spiked with dust particles, because most researchers have no analytical technique that is sufficient for investigating the both phytoplankton and bacterial communities in detail. Thus, there is little research on the effects of aerosolnutrient deposition and bioaerosol transport on the autochthonous phytoplankton and bacterial community structure at the level of community or individual species.

We designed an experiment to confirm the shifts in abundance of bacteria and phytoplankton by addition of dust particles into marine ecosystems using shipboard experiments. In this study, the combine of a $16 \mathrm{~S}$ rDNA clone library and a submersible-fluorometer analysis was used for clarifying the dynamics of the microbial community structure by dust fertilization and bioaerosol input. We collected dust particles from the snow layers on Mt. Tateyama and from the KOSA arrival area in China. The dust particles were used for incubation experiments on the ship with natural seawater samples.

\section{EXPERIMENT}

\section{1 Experiment Setting}

To assess the short-term response of phytoplankton and bacterial communities to aerosol deposition, we performed bioassay experiments on southern Kii Peninsula surface seawater using locally collected dust particles that had been recorded in the snow layers at Mt. Tateyama and dust particles collected from the Loess Plateau (China). The seawater samples were collected from the sea area from the seashore of Kii Peninsula at a distance of $150 \mathrm{~km}\left(33^{\circ} 29^{\prime} \mathrm{N}, 136^{\circ} 59^{\prime} \mathrm{E}\right)$ on 5 October 2009 during the SE0926 cruise of T/S Seisui Maru (Mie University) (Fig. 1). Three tanks of $20 \mathrm{~L}$ were filled with $18 \mathrm{~L}$ seawater and used for the experiment. Of the three tanks, one was established as a control and two received the dust particles that have been collected from the snow layers of Mt. Tateyama and the sand of the Loess Plateau at a concentration of $0.75 \mathrm{mg} \mathrm{L}^{-1}$ (about $12 \mathrm{mg}$ ). At the end of the experi-

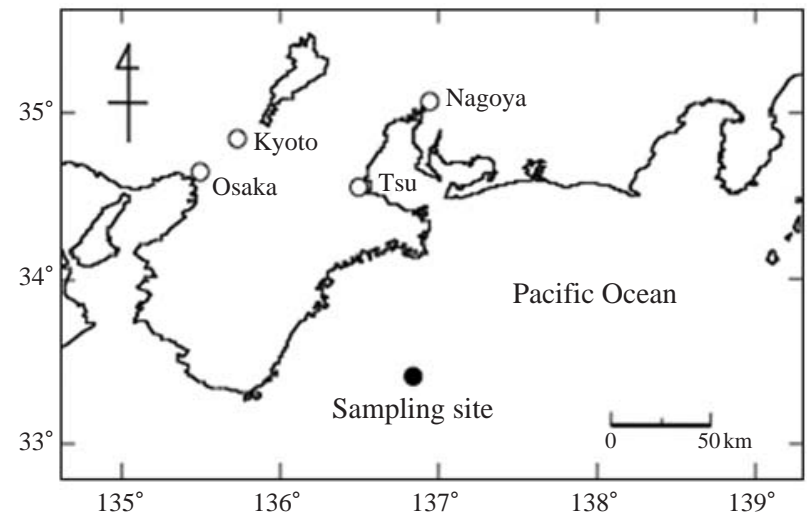

Fig. 1. Sampling sites.

ment, $30 \%$ of the air volume remained in the tanks. KOSA events carry between 0.5 and $6.0 \mathrm{mg}$ of dust $\mathrm{L}^{-1}$ on the North Pacific Ocean (Duce and Tindale, 1991). The amount of aerosol added to these incubations ( $12 \mathrm{mg}$ in $18 \mathrm{~L}$ ) corresponds to the expected dust input ( $\mathrm{mg} \mathrm{L}^{-1}$ of surface seawater) from cumulative deposition $\left(\mathrm{mg} \mathrm{m}^{-2}\right)$ at one dust event and a mixed layer of 10-20 m (typical dust storms in this region last from days to weeks).

The snow samples including dust particles were collected from the snow cover at Murododaira $(2,450$ $\mathrm{m}, \mathrm{MR}$ ) on Mt. Tateyama, where, during the winter and early spring, strong northwesterly winds result in heavy snowfall $(3,015 \mathrm{~m}$ above sea level) and the snowfall sometimes includes KOSA particles from China (Aoki et al., 2009; Osada et al., 2004). For the collection of snow samples, we used sampling bottles that were washed in a $3 \mathrm{~mol} / \mathrm{L} \mathrm{HCl}$ solution and sterilized at $121^{\circ} \mathrm{C}$ for $20 \mathrm{~min}$. The snow samples were allowed to melt at room temperature in the laboratory. The dust particles in the snow samples were collected using filtration with a $0.22 \mu \mathrm{m}$ pore-size polycarbonate filter (PC MB 47 MM 0.2 UM; Whatman, Tokyo, Japan) and then dried at $20^{\circ} \mathrm{C}$. The dust-particle samples were collected from the surface sand on the Loess Plateau.

Incubations were placed in a water pool adjusted to the temperature of surface seawater (about $24^{\circ} \mathrm{C}$ ) under ambient light conditions and over a 5-day period. After 0 day, 1 day, or 4 days of incubation, we monitored the response of bulk phytoplankton and bacteria and assessed the impact of the dust-particle addition on specific phytoplankton taxa and bacterial species composition. The concentration of total iron $\left(\mu \mathrm{mol} \mathrm{L} \mathrm{L}^{-1}\right)$ was determined.

The incubation bottles and the experimental equipment used in this incubation were washed with the 3 $\mathrm{mol} / \mathrm{L} \mathrm{HCl}$ solution to eliminate the contamination of metals, $\mathrm{N}$, and $\mathrm{P}$. 


\section{2 Structure of Phytoplankton}

A detailed description of a submersible fluorometer (FluoroProbe ver. 1.9 E1, MOLDAENKE, Kiel-Kronshagen, Germany) is provided in Beutler et al. (2002). Briefly, this device can be used to discriminate the differences in the pigment complexes originating from Cryptophyta, Bacillariophyta and Dinophyta, Cyanophyta, and Chlorophyta on the basis of the relative fluorescence intensity of chlorophyll (Chl) $a$ at $680 \mathrm{~nm}$ (due to the Photosystem II core pigments), following sequential light excitation by 5 light-emitting diodes (LEDs) emitting at 450, 525, 570, 590, and $610 \mathrm{~nm}$. Chl fluorescence emitted by the phytoplankton suspension was detected with a photomultiplier, and the accessory pigments of the light-harvesting complexes indicated a set of characteristic fingerprints of each phytoplankton group. The relative amount of each algal group was calculated to the equivalent amount of chlorophyll $a(\mathrm{Chl} a)\left(\mu \mathrm{g} \mathrm{L}^{-1}\right)$ using applicable software (FluoroProbe 1.6, bbe-Moldaenke). After the submersible fluorometer was set up into $2 \mathrm{~L}$ of seawater samples, measurements and calculations were performed every second during profiling for $1 \mathrm{~min}$.

For estimating the Chl $a$ concentration in the fractions of seawater samples, sample water $(200 \mathrm{~mL})$ was filtrated through a series of Nuclepore filter with pore sizes of 20,10 , and $2.0 \mu \mathrm{m}$, and a GF/F glass filter (ADTEC, Tokyo, Japan) to separate particles into four fractions: $>20 \mu \mathrm{m}, 10 \mu \mathrm{m}$ to $20 \mu \mathrm{m}, 2.0 \mu \mathrm{m}$ to 10 $\mu \mathrm{m}$, and $<2.0 \mu \mathrm{m}$. The $\mathrm{Chl} a$ retained on the filters was extracted in $\mathrm{N}, \mathrm{N}$-dimethylformamide at $-20^{\circ} \mathrm{C}$ for $24 \mathrm{~h}$ (Ishikawa and Furuya, 2004) and its concentration was determined by the fluorometric method of Parsons et al. (1984) with a Turner Design fluorometer Model 10-AU-005 (Turner Designs, CA, USA). After $\mathrm{HCl}$ solution was spiked to the sample solution, the fluorescence was measured again.

\section{3 Microbial Species Composition}

Ten $\mathrm{mL}$ of the seawater samples collected at 0 day, 1 day and 4 days of incubation was used for the extraction of genomic DNA using SDS (sodium dodecyl sulfate), proteinase $\mathrm{K}$, and lysozyme as described previously (Maki et al., 2010). Furthermore, the genomic DNA was purified by phenol-chloroform extraction, chloroform extraction, and ethanol precipitation. The 16S rDNA fragments (ca. 1,450 bp) of bacteria were amplified by PCR using the oligonucleotide primers, $27 \mathrm{~F}$ and $1492 \mathrm{R}$. These primers specifically bind to eubacterial $16 \mathrm{~S}$ rDNA. Thermal cycling was performed using a Program Temp Control System PC-700 (ASTEC, Fukuoka, Japan) under the following conditions: denaturation at $95^{\circ} \mathrm{C}$ for $1 \mathrm{~min}$, annealing at $57^{\circ} \mathrm{C}$ for $2 \mathrm{~min}$, and extension at $72^{\circ} \mathrm{C}$ for $2 \mathrm{~min}$ for a total of 30 cycles. The PCR amplicons of 16S rDNA fragments (ca. 1,450 bp) were cloned into Escherichia coli using a commercially prepared vector with a TA cloning kit (Invitrogen Co., CA, USA) according to the manufacturer's protocol. More than 20 of $16 \mathrm{~S}$ rDNA clones for one sample were obtained and the partial sequences (ca. $360 \mathrm{bp}$ ) were determined using a Dye Deoxy $^{\mathrm{TM}}$ Terminator Cycle Sequencing Kit (ABI, CA, USA) with the $27 \mathrm{~F}$ sequencing primer. The sequences determined were compared with a DDBJ database using a BLAST SEARCH program (Altschul et al., 1990).

\section{4 Determination of Bacterial Abundance}

Ten $\mathrm{mL}$ of seawater samples was fixed with a paraformaldehyde solution at a final concentration of $1 \%$. The samples were stained with DAPI (4',6-diamino-2phenylindole) at a final concentration of $0.5 \mu \mathrm{g} \mathrm{mL}-1$ for $15 \mathrm{~min}$ and filtrated through a $0.22 \mu \mathrm{m}$ pore-size polycarbonate filter (Whatman, Tokyo, Japan) stained with Sudan Black (Russell et al., 1974). After the filter was placed on a slide on top of a drop of low-fluorescence immersion oil, a drop of oil was added and then covered with a cover slide. Slides were examined using an epifluorescence microscope (Olympus, Tokyo, Japan) with a UV excitation system. A filter transect was scanned, and the bacterial particles on the filter transect were counted. The detection limit of particles was below $10^{4}$ particle $\mathrm{mL}^{-1}$.

\subsection{Measurements of the Concentrations of Metal and Nutrients and the COD}

The water subsamples were filtrated through a 0.45 $\mu \mathrm{m}$ cellulose ester filter (Millipore, Tokyo, Japan). The metal concentrations in the filtrate were determined by an ICP (inductively coupled plasma) emission spectrometry OPTIMA 3300XL (Perkin Elmer, MA, USA). In this experiment, the detection limit of metal was below $1.0 \mathrm{nmol} \mathrm{L}^{-1}$.

Total phosphorus (particles and dissolved organic phosphorus and inorganic phosphorus) was determined in the subsamples after an acid persulphate oxidation followed by a spectrophotometetric analysis using the molybdenum blue method (APHA). The nitrate concentrations were measured with colorimetric analysis using sulfanilamide (APHA, 1989). The concentrations of DOC were determined using a $\mathrm{K}_{2} \mathrm{MnO}_{4}$ oxidation technique.

\section{RESULTS AND DISCUSSION}

We found that the dust particles of Mt. Tateyama did not indicate significant dynamics of metal elements (Table 1). The $\mathrm{N}$ (combined nitrate and ammonium) 
Table 1. Metal element concentrations, nutrient concentrations and COD in the seawater samples spiked with the dust particles of Mt. Tateyama and Loess Plateau and without dust particles (control).

\begin{tabular}{|c|c|c|c|c|c|c|c|c|c|c|}
\hline & \multicolumn{7}{|c|}{ Metal elements (nmol L $\left.{ }^{-1}\right)$} & \multicolumn{2}{|c|}{$\begin{array}{c}\text { Nutrients } \\
\left(\mu \mathrm{mol} \mathrm{L}^{-1}\right)\end{array}$} & \multirow{2}{*}{$\begin{array}{c}\mathrm{COD} \\
\left(\mathrm{O}_{2} \mathrm{mg} \mathrm{L}^{-1}\right.\end{array}$} \\
\hline & Co & $\mathrm{Cu}$ & $\mathrm{Fe}$ & $\mathrm{Mn}$ & $\mathrm{Ni}$ & $\mathrm{Pb}$ & $\mathrm{Zn}$ & $\mathrm{N}$ & $\mathrm{P}$ & \\
\hline Mt. Tateyama & 1.4 & 1.9 & 7.7 & 1.8 & 7.3 & N.D. & N.D. & 0.46 & 0.025 & 4.55 \\
\hline Loess Plateau & 3.9 & 6 & 6.9 & 1.8 & 9.9 & N.D. & N.D. & 0.52 & 0.007 & 4.57 \\
\hline Control & 1.4 & 1 & 6.5 & 1.8 & 3.5 & N.D. & N.D. & 0.54 & 0.004 & 3.99 \\
\hline
\end{tabular}

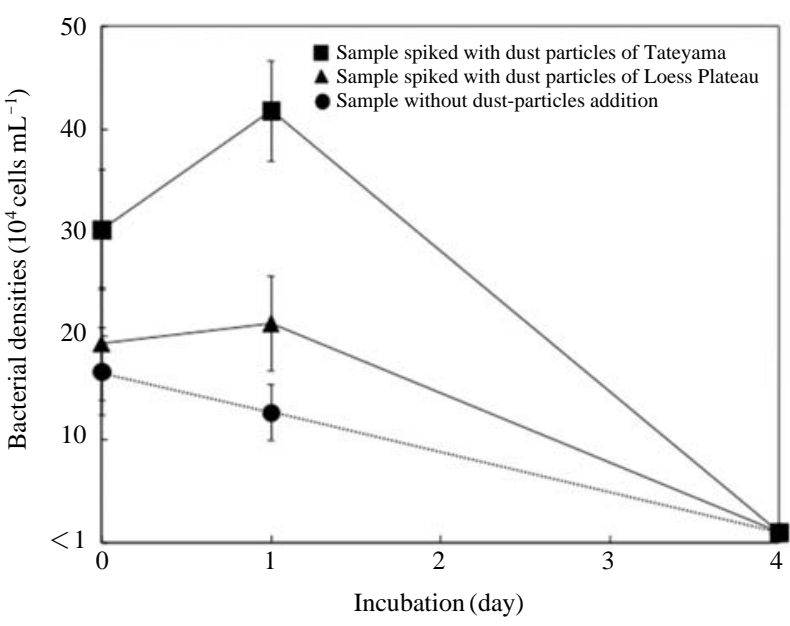

Fig. 2. Change in bacterial cell densities in seawater samples spiked with dust particles of Tateyama (Squares), those spiked with dust particles of the Loess Plateau (Triangles), and those without dust particles (Circles).

and $\mathrm{P}$ (phosphate) concentrations did not increase in the dust particle treatments. Laboratory experiments, field observations, and numerical simulations all suggested that, in some of the ocean areas, nutrient addition by dust deposition could increase primary production, export production, and carbon sequestration (Erickson et al., 2003). However, at the marine coastal region of the Kii Peninsula, where the investigation was conducted, $\mathrm{Fe}$ and $\mathrm{N}$ were at relatively high concentrations, and, thus, the effects of nutrients and elements of the dust particles were not considered. During the investigation, a typhoon was making landfall in Japan and mixing the marine environment. This turbulence might move nutrients and elements in the seawater from the middle layers to the surface area or from the coastal shore to the sampling area. Moreover, there is possibility that the strong wind cause the contamination of nutrients and elements into the seawater samples. The amounts of $\mathrm{P}$ that were released from the dust particles were insufficient to increase the concentrations of $\mathrm{P}$ in the seawater samples. In contrast, the dust particles treatments increased the COD, suggesting that the dust particles provide organic carbon

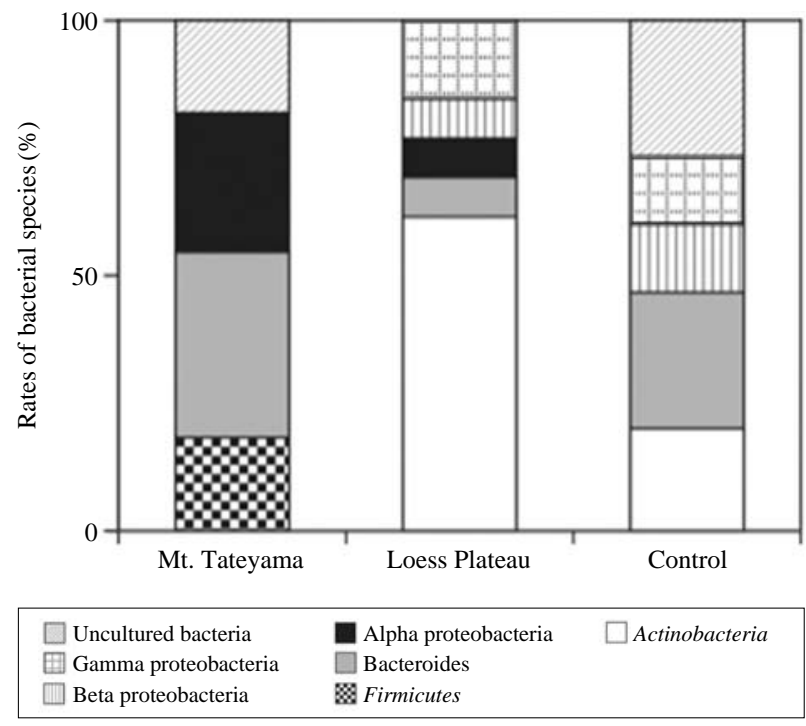

Fig. 3. Composition of the partial sequences of $16 \mathrm{~S}$ rDNA clones (ca. $409 \mathrm{bp}$ ) obtained from the seawater samples spiked with dust particles of Mt. Tateyama and the Loess Plateau and without dust particles. The samples were used after the incubation of 1 day.

to the seawater (Table 1). In a previous study, we demonstrated that the dust particles originated from KOSA events and that the bacteria associated with the dust particles could have been transported from China (Maki et al., 2010). It has been reported that airborne bacteria can travel associated with dust particles (Kellogg and Griffin, 2006). Allochthonous bacteria associated with the dust particles may grow in the seawater samples spiked with the dust particles.

The seawater samples spiked with dust particles showed an increase in bacterial cell density of 1.2-2.5 times from the values of the control on the first day of incubation (Fig. 2), and the bacterial particles decreased to densities below the detection limit after 4 days of incubation. Responses such as bacterial abundance and activity related to the addition of dust particles had been reported earlier (Bonnet et al., 2005; Herut et al., 2005), even though these authors did not measure the detailed dynamics of the bacterial structure. Pulido- 

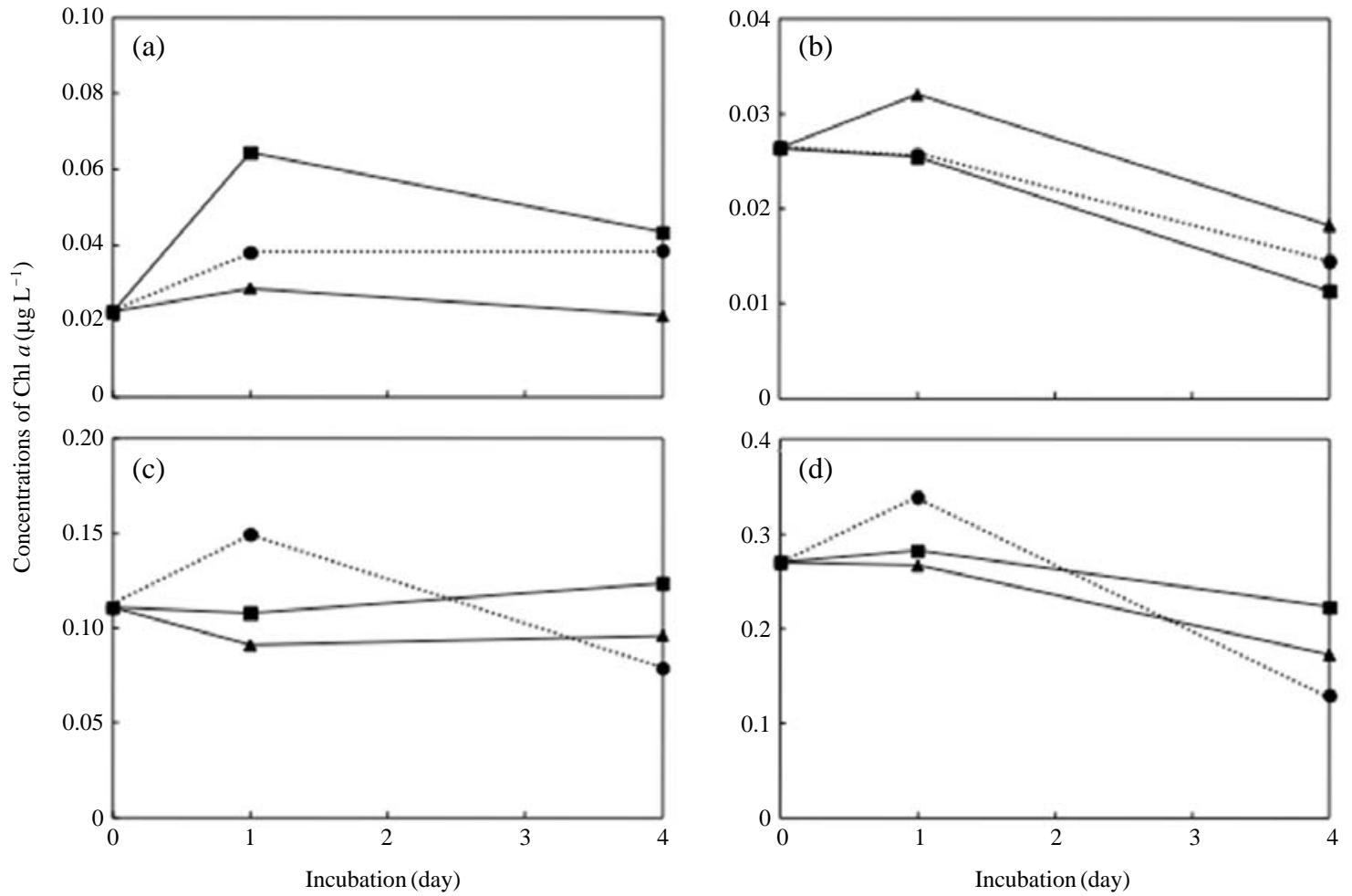

Fig. 4. Change in chlorophyll concentrations in the seawater-subsample fractions of $>20 \mu \mathrm{m}$ (a), 10-20 $\mu \mathrm{m}$ (b), 2.0-10 $\mu \mathrm{m}$ (c), and $<2.0 \mu \mathrm{m}(\mathrm{d})$ in seawater samples spiked with dust particles of Mt. Tateyama (Squares) and the Loess Plateau (Triangles) and those without dust particles (Circles).
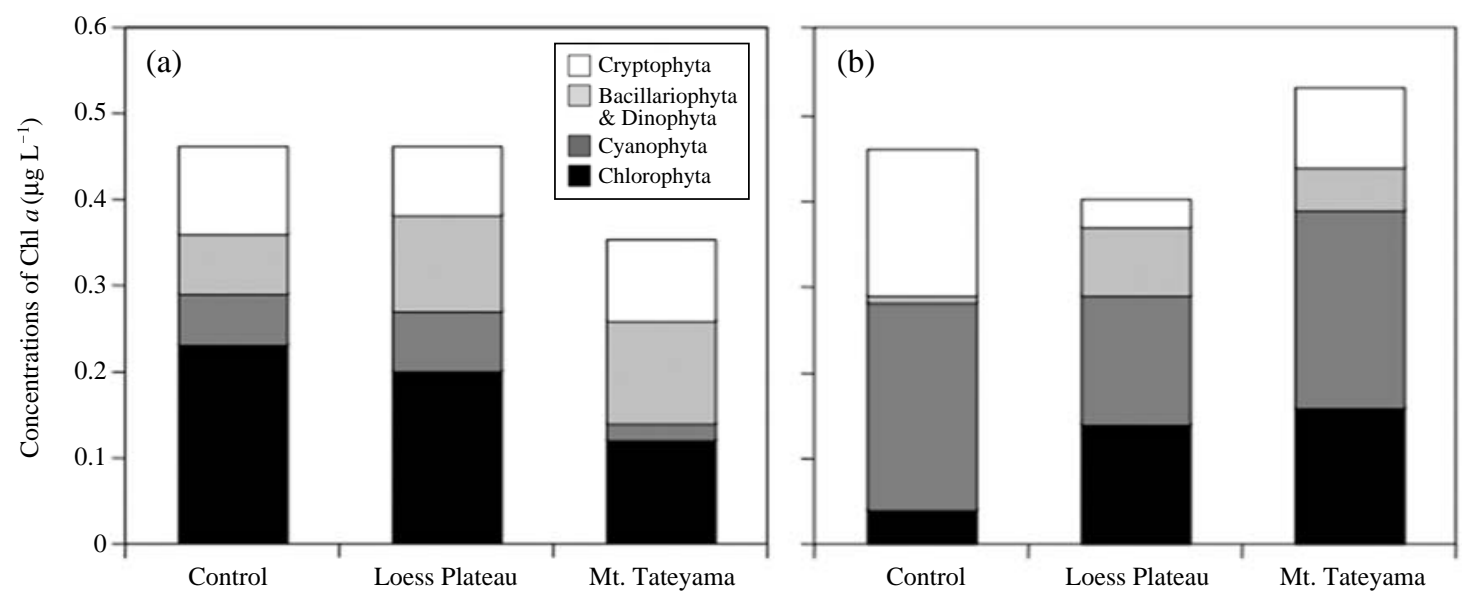

Fig. 5. Concentrations of chlorophyll fraction of Chlorophyta, Cyanophyta, Bacillariophyta and Dinophyta, and Cryptophyta determined using a submersible fluorometer in cultures without dust-particle addition, including the dust particles collected from Mt. Tateyama and the Loess Plateau, which were incubated for 1 day (a) and 4 days (b).

Villena et al. (2008) reported that the dust addition experiments increased bacterial abundance and respiration at 1.5- to 3 -fold increases. When a total of 39 clones of 16S rDNA were obtained from seawater samples and their partial sequences (ca. $300 \mathrm{bp}$ ) were determined, the sequences belonged to several bacterial groups, and some of them indicated unknown sequences (Fig. 3). The addition of dust particles resulted in the appearance of bacterial communities belonging to the Actinobacteria and Firmicutes groups and the 
alpha-proteobacteria. These bacterial species were detected from the bacterial communities associated with the dust particles at Mt. Tateyama (Maki et al., 2011). Some studies reported that, in particular, the members of Firmicutes were detected from the atmospheric aerosols and transported by dust events (e.g., Kellogg et al., 2004). Moreover, organic matter was reported to stimulate the growth of heterotrophic bacteria (Lekunberri et al., 2010). The addition of dust particles in seawater samples would increase the biomass of a specific bacterial group in a marine environment and/or carry the bacterial species.

There were no increases in total $\mathrm{Chl} a$ relative to the dust particle treatment. The amounts of Chl $a$ at four size fractions indicated similar dynamics between the addition of dust particles and the control (Fig. 4). In contrast, the analysis using a submersible fluorometer revealed that the addition of dust particles increased the fluorescence fractions of Bacillariophyta and Dinophyta, and Chlorophyta (Fig. 5). The microalgal bloom requires essential compounds, such as vitamins, produced by bacteria (Haines and Guillard, 1974). Baker et al. (2006) reported that the aerosols were able to supply bioavailable nutrients and reverse nutrient limitation of the bacterial and phytoplankton communities. Some species of dinoflagellates are known to obtain nutrients using mixotrophy, which combines photosynthesis and phagotrophy (Cole, 1982). The bacterivorous behavior of some microalgae is known to contribute to their nutrition when light and/or nutrients limit photosynthesis (Keller et al., 1994). The addition of dust particles could increase bacterial abundance by the addition of organic matter and/or by the immigration of bacterial communities associated with mineral dust. The bacterial components may contemporary support the growth of some sizes of phytoplankton, and disappear within a few days.

We suggest that, after bacterial abundance was increased by the addition of dust particles, the phototrophic microorganisms that use the bacterial products and/or grazed on the bacterial cells as a result of mixotrophy will grow. We show that this deposition can potentially alter the patterns of the marine primary production and community structure of bacterial communities in the Pacific Ocean. However, a typhoon could have mixed the seawater in sampling area, provide the nutrient, and store elements from the middle layer or shore are of the sea. Possibly, the strong wind causes the contamination of elements and the turbulence of microbial communities in the sea. In subsequent research on a marine area under normal conditions, the effect of the addition of dust particles on microbial communities will be elucidated.

\section{ACKNOWLEDGEMENTS}

We are grateful to the captain and crew of the T/S Seisui Maru for their support at sea. This research was supported by a Grant-in-Aid for the Encouragement of Young Scientists (22681005) from the Ministry of Education, Science, Sports, and Culture, Japan. The Global Environment Research Fund (B-0901,C1155) provided by the Ministry of the Environment of Japan also supported this work.

\section{REFERENCES}

Altschul, S.F., Gish, W., Miller, W., Myers, E.W., Lipman, D.J. (1990) Basic local alignment search tool. Journal of Molecular Biology 215, 403-410.

Aoki, K., Watanabe, K. (2009). Measurements of atmospheric aerosol at Mt. Tateyama, Japan. Earozoru Kenkyu 24, 112-116. (in Japanese)

APHA, AWWA, WPCF (1989) Standard methods for the examination of water and wastewater, 17th edn. American Public Health Association, Washington, D.C.

Baker, A.R., Jickells, T.D., Witt, M., Linge, K.L. (2006) Trends in the solubility of iron, aluminium, manganese and phosphorus in aerosol collected over the Atlantic Ocean. Marine Chemistry 98, 43-58.

Beutler, M., Wiltshire, K.H., Meyer, B., Moldaenke, C., Luring, C., Meyerhofer, M., Hansen, U.P., Dau, H. (2002) A fluorometric method for the differentiation of algal populations in vivo and in situ. Photosynthesis Research 72, 39-53.

Blank, M., Leinen, M., Prospero, J.M. (1985) Major Asian aeolian inputs indicated by the mineralogy of aerosols and sediments in the western North Pacific. Nature 314, 84-86.

Bonnet, S., Guieu, C., Chiaverinni, J., Ras, J., Stock, A. (2005) Effect of atmospheric nutrients on the autotrophic communities in a low nutrient, low chlorophyll system. Limnology Oceanography 50, 1810-1819.

Cole, J.J. (1982) Interactions between bacteria and algae in aquatic ecosystems. Annual Review of Ecology, Evolution, and Systematics 13, 291-314.

Donaghay, P.L., Liss, P.S., Duce, R.A., Kester, D.R., Hanson, A.K., Villareal, T., Tindale, N.W., Gifford, D.J. (1991) The role of episodic atmospheric nutrient inputs in the chemical and biological dynamics of oceanic ecosystems. Oceanography 4, 62-70.

Duce, R.A., Tindale, N.W. (1991) Atmospheric transport of iron and its deposition in the ocean; Chemistry and biology of iron and other trace metals. Limnology Oceanography 36, 1715-1726.

Erickson III, D.J., Hernandez, J.L., Ginoux, P., Gregg, W.W., McClain, C., Christian, J. (2003) Atmospheric iron delivery and surface ocean biological activity in the Southern Ocean and Patagonian region. Geophysic 
Research Letter 30, 1609-1613.

Haines, K.C., Guillard, R.R.L. (1974) Growth of vitamin B12-requiring marine diatoms in mixed laboratory cultures with vitamin $\mathrm{B}_{12}$-producing marine bacteria. Journal of Phycology 10, 245-252.

Herut, B., Zohary, T., Krom, M.D., Mantoura, R.F.C., Pitta, P., Psarra, S., Rassoulzadegan, F., Tanaka, T., Thingstad, T.F. (2005) Response of east Mediterranean surface water to Saharan dust: on-board microcosm experiment and field observations. Deep-Sea Res. II 52, 3024-3040.

Hervàs, A., Camarero, L., Reche, I., Casamayor, E.O. (2009) Viability and potential for immigration of airborne bacteria from Africa that reach high mountain lakes in Europe. Environmental Microbiology 11, 16121623.

Ishikawa, A., Furuya, K. (2004) The role of diatom resting stages in the onset of the spring bloom in the East China Sea. Marine Biology 145, 633-639.

Iwasaka, Y., Shi, G.Y., Yamada, M., Kobayashi, F., Kakikawa, M., Maki, T., Chen, B., Tobo, Y., Hong, C. (2009). Mixture of Kosa (Asian dust) and bioaerosols detected in the atmosphere over the Kosa particles source regions with balloon-borne measurements: possibility of long-range transport. Air Quality, Atmosphere \& Health 2, 29-38.

Keller, K.D., Shapiro, L.P., Haugen, E.M., Cucci, T.L., Sherr, E.B. (1994) Phagotrophy of fluorescently labeled bacteria by an oceanic phytoplankton. Microbiological Ecology 28, 39-52.

Kellogg, C.A., Griffin, D.W. (2006) Aerobiology and the global transport of desert dust. Trends Ecological Evolution 21, 638-644.

Kellogg, C.A., Griffin, D.W., Garrison, V.H., Peak, K.K., Royal, N., Smith, R.R., Shinn, E.A. (2004) Characterization of aerosolized bacteria and fungi from desert dust events in Mali, West Africa. Aerobiologia 20, 99110 .

Lekunberri, I., Lefort, T., Romero, E., Vázquez-Domínguez, E., Romera-Castillo, C., Marrasé, C., Peters, F., Weinbauer, M., Gasol, J.M. (2010) Effects of a dust deposition event on coastal marine microbial abundance and activity, bacterial community structure and ecosystem function. Journal of Plankton Research 32, 381396.

Maki, T., Aoki, S., Susuki, S., Kobayashi, F., Kakikawa, M., Hasegawa, H., Iwasaka, Y. (2011) Characterization of halotolerant and oligotrophic bacterial communities in Asian desert dust (KOSA) bioaerosol accumulated in layers of snow on Mount Tateyama, Central Japan. Aerobiologia, in press. DOI 10.1007/s10453-011-9196-0.

Maki, T., Susuki, S., Kobayashi, F., Kakikawa, M., Tobo, Y., Yamada, M., Higashi, T., Matsuki, A., Hong, C., Hasegawa, H., Iwasaka, Y. (2010) Phylogenetic analysis of atmospheric halotolerant bacterial communities at high altitude in an Asian dust (KOSA) arrival region, Suzu City. Science of Total Environment 408, 45564562.

Moore, J.K., Doney, S.C., Lindsay, K., Mahowald, N., Michaels, A.F. (2006) Nitrogen fixation amplifies the ocean biogeochemical response to decadal timescale variations in mineral dust deposition. Tellus 58B, 560572.

Osada, K., Iida, H., Kido, M., Matsunaga, K., Iwasaka, Y. (2004) Mineral dust layers in snow at Mount Tateyama, Central Japan: formation processes and characteristics. Tellus 56B, 382-392.

Parsons, T.R., Maita, Y., Lalli, C.M. (1984) A manual of chemical and biological methods for seawater analysis. Pergamon, Oxford.

Paytan, A., Mackey, K.R.M., Chen, Y., Lima, I.D., Doney, S.C., Mahowald, N., Labiosa, R., Post, A.F. (2009) Toxicity of atmospheric aerosols on marine phytoplankton. Proceedings of the National Academy of Sciences 106, 4601-4605.

Prospero, J.M., Savoie, D.L. (1989) Effect of continental sources on nitrate concentrations over the Pacific Ocean. Nature 339, 687-689

Pulido-Villena, E., Wagener, T., Guieu, C. (2008) Bacterial response to dust pulses in the western Mediterranean: implications for carbon cycling in the oligotrophic ocean. Global Biogeochemistry Cycles 22, doi:10.1029/ 2007GB003091.

Russell, W.C., Newman, C., Williamson, D.H. (1974). A simple cytochemical technique for demonstration of DNA in cells infected with mycoplasms and viruses. Nature 253, 461-462.

Spokes, L.J., Jickells, T.D. (1996) Factors controlling the solubility of aerosol trace metals in the atmosphere and on mixing into seawater. Aquatic Geochemistry 1, 355374.

(Received 28 December 2010, revised 4 April 2011, accepted 9 April 2011) 